\title{
The Potential Effect of Citrus Sinensis Extract on Malondialdehyde (MDA) Levels in Rat Induced by Cigarette Smoke
}

\author{
Ika Setyawati ${ }^{1{ }^{*}}$ Nunki Indah Hidayati ${ }^{2}$
}

\begin{abstract}
${ }^{1}$ Department of Biochemystri, School of Medicine, Faculty of Medicine and Health Sciences, Universitas Muhammadiyah Yogyakarta, Yogyakarta, Indonesia

${ }^{2}$ School of Medicine, Faculty of Medicine and Health Sciences, Universitas Muhammadiyah Yogyakarta, Yogyakarta, Indonesia ${ }^{*}$ Corresponding author. Email: ikasetyawati.dr@umy.ac.id
\end{abstract}

\begin{abstract}
Cigarette smoke contains numerous substances containing free radicals and can prompt oxidative pressure. The buildup of free radicals cannot be neutralized by antioxidants for essential cancer prevention agent supplements from outside. In relation to that, the peel of citrus sinensis is expected to contain cell reinforcements that may eliminate free radicals. This study aims to determine the potential effect of Citrus sinensis peel extract on MDA levels in rats induced by cigarette smoke. This investigation is an experimental study with pre and post-test control groups. The 25 subjects of Rattus Norvergicus were divided into five groups: normal group, positive group, Treatment 1 (37.5 mg/kg BW Citrus sinensis peel extract), Treatment 2 (75 mg/kg BW Citrus sinensis peel extract) and Treatment $3(112.5 \mathrm{mg} / \mathrm{kg}$ BW Citrus sinensis peel extract). Analysis of statistics resulted in a huge distinction between pre-test and post-test with p-value $<0.05$ (Wilcoxon test). Consequently, the Kruskal-Wallis was applied to distinguish the expansion of MDA levels pre-test and post-test. The investigation showed that the distinction was in the most significant levels in the positive group $(7.71 \mathrm{nmol} / \mathrm{mL})$, the least in the negative group $(0.09 \mathrm{nmol} / \mathrm{mL})$, and $37.5 \mathrm{mg} / \mathrm{kg} \mathrm{Citrus}$ sinensis peel extract group $(0.96 \mathrm{nmol} / \mathrm{mL})$ was the most reduced among the treatment groups. There are huge contrasts in all treatment groups with $\mathrm{p}=0.000(\mathrm{p}<0.05)$. The investigation inferred that the concentrate of Citrus sinensis could lessen levels of MDA in Rattus Norvergicus prompted by cigarette smoke.
\end{abstract}

Keywords: cigarette smoke, Citrus sinensis, MDA, Rattus Norvergicus

\section{INTRODUCTION}

Smoking causes death and a danger to the whole population since it averagely slaughters six million individuals every year. Out of those numbers, more than five million are smokers and ex-active smokers, while 600,000 are passive smokers or non-smokers [1]. Smoking behavior in Indonesia keep increasing within age 15 from $34.2 \%$ (2007) to $36.3 \%$ (2013), and active smokers consist of $64.9 \%$ men and $2.1 \%$ women [2]. The level of smoking behavior dan knowledge for most respondents had a negative attitude, with 63.3\% [3]. The Global Adult Tobacco Survey (GATS) stated that cigarette users in Indonesia reached $67.4 \%$ for men and $4.5 \%$ for women or equivalent to 61.4 million adult smokers [4].

Cigarette smoke contains oxidants and prooxidants that hideously produce free radicals and cause oxidative stress [5]. Free radicals must be eliminated by the body's antioxidants, but due to excessive production of free radicals or the hindered antioxidants, it undoubtedly disrupt the balance between free radicals and antioxidants, and this condition is called oxidative stress [6] [7].

The accumulation of radical compounds eventually damages the biomolecules such as lipids, proteins, or DNA, characterized by malondialdehyde (MDA), lipid hydroperoxides (LOOH), and 4-hydroxy-2-nonenal for lipids, carbonyl protein (CPs) and 8-OH to measure damage protein and DNA [8].

Phenolic compounds, especially flavonoids, are the main contributors of antioxidants in the skin of the fruit [9] [10]. Citrus sinensis contains calcium, vitamin C, liminoids, magnesium, pectin, folacin, hesperidin flavonoids, potassium, polyphenols, thiamine, synephrine, and niacin that have an essential role in preventing increasing cholesterol levels, high blood pressure, cancer, arteriosclerosis, stomach ulcers and kidney stones [11].

\section{METHODS AND MATERIALS}

\subsection{Experimental Design}

The citrus sinensis peel extract was administered on a single dose per day. The rats were then divided into 5 groups ( $\mathrm{n}=5$ rats /group): normal rats, positive control, Treatment 1 : $37.5 \mathrm{mg} / \mathrm{kg} \mathrm{BW} /$ day Citrus sinensis peel extract + cigarette smoke, Treatment 2: $75 \mathrm{mg} / \mathrm{kg} \mathrm{BW} /$ day Citrus sinensis peel extract + cigarette smoke, Treatment 3: $112.5 \mathrm{mg} / \mathrm{kg} \mathrm{BW/day}$ Citrus sinensis peel extract + cigarette smoke.

MDA levels were determined by the method of Thiobarbituric acid-reactive substances (TBARs). MDA blood tests were through a method described by Wuryastuti (1996) in Indonesian food and nutrition progress, 2000 Vol. 7 
no. 2. A total of $0.75 \mathrm{~mL}$ of phosphoric acid was put into a polypropylene tube with $0.25 \mathrm{~mL}$ of thiobarbituric acid (TBA) solution.

\subsection{Material}

Sweet orange (Citrus sinensis) peel was purchased from the local grocery. Sweet oranges were then washed, peeled, and after that, the orange peel was dried at a temperature of $40^{\circ} \mathrm{C}$. Next, the dried orange peel was blended with Simplicia. One hundred grams of Simplicia was mixed with a solvent in the form of $70 \%$ ethanol $(800 \mathrm{~mL})$ and maceration for 48 hours while occasionally stirred. For the next step, it was filtered until two substances were obtained, the pulp and maserat. The results of maceration or maserat were put into a rotary evaporator and became a thick extract.

\subsection{Samples of MDA Levels}

The sample for the MDA level test was serum. The serum was obtained by allowing the blood to clot for 1 hour at room temperature, then messed around at $3000 \mathrm{rpm}$ for 10 minutes.

\subsection{Animals}

This study used 25 physically healthy white male rats (Rattus Novergicus) aged between 2 - 3 months with weight $\pm 200 \mathrm{~g}$. The rats were adapted for three days at Central InterUniversity Building, Laboratory of the Center for Food and Nutrition Studies, Gajah Mada University with adequate feeding with standard pellet rats diet, drinking, and lighting at room temperature. Consequently, this study abode all proper ethics.

\subsection{Induction of Cigarette Smoke}

Cigarette smoke was obtained from kretek cigarettes without side flow filters induced at a dose of 2 cigarettes a day.

\subsection{Data Analysis}

The data were processed using the Kruskal-Wallis test followed by the Mann Whitney U test to compare differences in MDA levels between treatment groups in the administration of sweet orange peel extract. The value is significant if $\mathrm{p}<0.05$.

\section{RESULTS AND DISCUSSION}

The data distribution was tested using the Shapiro-Wilk normality test, and the results of the data analysis were not normally distributed. The significance of the differences in pre-test and post-test MDA levels was determined by using the Wilcoxon statistical analysis test. The statistical analysis of differences in MDA levels pre-test and post-test can be seen in table 1.
Table 1. The Difference of Mean MDA Levels of Rattus Norvergicus Pre-test and Post-test Induced By Cigarette Smoke and Given Sweet Orange Peel Extract (Citrus sinensis)

\begin{tabular}{|c|c|c|c|c|}
\hline $\begin{array}{c}\text { Wilcoxon } \\
\text { test }\end{array}$ & $\begin{array}{c}\text { Valid } \\
\mathrm{N}\end{array}$ & $\begin{array}{c}\text { Levels of MDA } \\
(\mathrm{nmol} / \mathrm{mL}) \pm \\
\mathrm{SD} \\
\text { (Pretest) }\end{array}$ & $\begin{array}{c}\text { Levels of } \\
\text { MDA }(\mathrm{nmol} / \mathrm{mL}) \pm \\
\text { SD } \\
\text { (Prostest) }\end{array}$ & $\begin{array}{c}\mathrm{p}- \\
\text { level }\end{array}$ \\
\hline Normal rats & 5 & $1.08 \pm 0.08$ & $1.17 \pm 0.13$ & 0.043 \\
\hline $\begin{array}{c}\text { Positive } \\
\text { control }\end{array}$ & 5 & $1.18 \pm 0.19$ & $8.90 \pm 0.33$ & 0.042 \\
\hline Treatment 1 & 5 & $1.21 \pm 0.12$ & $7.37 \pm 0.26$ & 0.043 \\
\hline Treatment 2 & 5 & $1.16 \pm 0.16$ & $4.30 \pm 0.29$ & 0.043 \\
\hline Treatment 3 & 5 & $1.44 \pm 0.18$ & $2.40 \pm 0.13$ & 0.043 \\
\hline \multicolumn{7}{|c|}{ The Difference of MDA Levels pre-test and post-test are } \\
significant at p $<0.05$
\end{tabular}

The difference test in table 1 shows that the p-value is significant in all groups $(\mathrm{p}<0.05)$. Table 1 shows that the positive group experienced the highest average increase in MDA levels compared to the other groups with 7.71 $\mathrm{nmol} / \mathrm{mL}$. The increase in MDA levels in the positive group indicates that exposure to cigarette smoke causes oxidative stress, which then triggers lipid peroxidation and increases MDA production in the body [12]. The plasma MDA levels are higher in smokers than in non-smokers. This study was conducted on 100 subjects with 50 healthy subjects and 50 chronic or heavy smokers and obtained significant results with $\mathrm{p}$-value $=0.0001(\mathrm{p}<0.05)$ [13]. Other studies have also shown increased levels of MDA in rats exposed to cigarette smoke as many as 40 cigarettes per day $(\mathrm{p}<0.05)$ [14].

In the normal group, MDA levels were lower than the treatment group because the MDA levels were very dependent on the amount of oxidative stress and could only be neutralized by antioxidants, while under normal conditions, MDA levels could be formed at low levels. When normal conditions, lipid peroxidation in the body can still be overcome by natural antioxidants (endogenous antioxidants), namely catalase, superoxide dismutase (SOD) and glutathione peroxidase [15].

\section{Table 2. Results of The Inter-Group Comparison Test}

\begin{tabular}{|l|l|l|}
\hline Mann Whitney Test & Inter Group & p-level \\
\hline \multirow{5}{*}{ Normal rats } & Positive control & 0.009 \\
\cline { 2 - 3 } & Treatment 1 & 0.009 \\
\cline { 2 - 3 } & Treatment 2 & 0.009 \\
\cline { 2 - 3 } & Treatment 3 & 0.009 \\
\hline Positive control & Treatment 1 & 0.009 \\
\cline { 2 - 3 } & Treatment 2 & 0.009 \\
\cline { 2 - 3 } & Treatment 3 & 0.009 \\
\hline Treatment 1 & Treatment 2 & 0.009 \\
\cline { 2 - 3 } & Treatment 3 & 0.009 \\
\hline Treatment 2 & Treatment 3 & 0.009 \\
\hline The Inter-Group Comparison Test are significant at p < 0.05
\end{tabular}

Table 2 shows that the results of the mean MDA levels in Treatment group 1, 2, and 3 experienced a significant decrease when compared to the positive group $(\mathrm{p}=0.009)$. The decrease in MDA levels (when compared to the positive group) indicates that the orange peel extract contains the main 
phenolic compounds, namely hydroxycinnamic acid (HCA) and flavonoids, which act as antioxidants [16]. Orange peel extract can reduce MDA levels $(\mathrm{p}=0.001)$ in the heart and liver tissue [17]. Other research suggests orange peel extract does a potent hepatoprotective effect because it prevented oxidative damage in mice induced with paracetamol [18].

Orange peels contain good radical antioxidative potential and a high antioxidant concentration compared to the pulp [10] [16]. Antioxidants stabilize radicals by complementing the lack of electrons that free radicals have and inhibiting chain reactions for the formation of free radicals resulting in cell damage [19].

The action mechanism of flavonoids as antioxidants was to suppress ROS formation (Reactive Oxygen Species) by inhibiting enzymes in the formation of ROS and increasing regulation and protection of antioxidants. Flavonoids can also protect membrane lipids from oxidative damage so that lipid peroxidation can be inhibited and increased levels of Malondialdehyde (MDA) can be prevented [20][21].

\section{CONCLUSION}

The administration of orange peel extract (Citrus sinensis) can reduce MDA levels in animals induced by cigarette smoke.

\section{ACKNOWLEDGMENTS}

The research teams appreciated the Research, Publication and Community Service Institute (LP3M) for the research funding through internal university grants.

\section{REFERENCES}

[1] World Health Organization. (2011). Global Tobacco Epidemic.

[2] RI Ministry of Health, Basic Health Research, Ministry of Health of the Republic of Indonesia (Riskesdas), Jakarta, 2013.

[3] Septian, E., Jatmika, D., Maulana, M. (2015). Perilaku Merokok Pada Penderita Hipertensi Di Desa Sidokarto Kecamatan Godean, Sleman, Yogyakarta Kesmas, Vol.9, No.1, Maret 2015, pp. $53-60$

[4] World Health Organization. (2011). Global Adult Tobacco Survey, Indonesia Report.

[5] Arinola O.G., Akinosun O.M. \& Olaniyi J.A. (2011). Passive- and active cigarrete smoking : Effects on the levels of antioxidants vitamins, immunoglobulin classes and acute phase reactants. African J Biotech, 10, 61306132.

[6] Birben, E., Sahiner, U. M., Sackensen, C., Erzurum, S., Kalayci, O. (2012). Oxidative stress and antioxidant defense. WAO Jurnal.

[7] Astuti, S., Muchtadi, D., Astawan, M., Purwantara, B. \&Wresdiyati, T. (2008). Kadar peroksidasi lipid dan aktivitas superoksida dismutase (SOD) testis tikus yang diberi tepung kedelai kaya isoflavon, seng ( $\mathrm{Zn}$ ) dan vitamin E. Majalah Kedokteran Bandung 40(2) (In Press).

[8] Seven A, Gu* zel S, Aslan M, Hamuryudan V. (2008). Lipid, protein, DNA oxidation and antioxidant status in rheumatoid arthritis. Clin Biochem, 41, 538-43.

[9] Zulkifli, K.S., Abdullah, N., Abdullah, A., Aziman, N dan Kamarudin S.S.W. (2012). Bioactive phenolic compound and antioxidant activity of selected fruits peels. International Conference on Environment, Chemistry and Biology, 49, 66-70.

[10] Hegazy, A. E., Ibrahium, M. I. (2012). Antioxidant activities of orange peel extract. Indonesian Food and Nutrition Progress (2000) Vol. 7 No. 2

[11]Etebu, A., Nwauzoma, A. B. (2014). A review on sweet orange (citrus sinensis 1 osbeck): health, diseases and management. American Journal of Research Communication, 2(2), 33-70.

[12] Permatasari F.R., Marhendra A. P. W., Aulanni‘am. (2013). Studi terapi ekstrak kulit buah manggis (Garcinia mangostana L.) terhadap penurunan kadar malondialdehyde (MDA) pada organ testis dan jumlah spermatozoa tikus (Rattus norvegicus) hasil induksi paparan asap rokok. Karya Tulis Ilmiah strata satu Program Studi Kedokteran Hewan, Universitas Brawijaya, Malang.

[13] Kumar S., Mahat R.K. \& Batra J. (2015). Evaluation of lipid parameters, liver function test, CRP and MDA (as a marker of lipid peroxidation) in chronic cigarrete smokers. International Journal of Biomedical and Advance Research, 6 (02), 115-119.

[14]Zhou, X., Zhao, L., Mao, J., Huang, J., Chen, J. (2015). Antioxidant Effects of Hydrogen Sulfide on Left Ventricular Remodeling in Smoking Rats Are Mediated via PI3K/Akt-Dependent Activation of Nrf2 Toxicological Sciences Vol. 144, No.1

[15]Latifa, K. I. (2015). Profil Kadar MDA (Malondialdehide) Pada Tikus yang diberikan Ekstrak Herba Thymi (Thymus Vulgaris [L.]). Skripsi diterbitkan. Surakarta : Fakultas Farmasi UMS.

[16] Park, J.H., Lee, M., Park, E. (2014). Antioxidant Activity of Orange Flesh and Peel Extracted with various Solvents. Prev. Nutr. Food Sci. 19 (4), 291-298.

[17] Ciftci, M., Simsek, U.G., Dalkilic, B., Azman, M.A., Yilmaz, O., Mutlu, S.I., et al. 2016. Effect of dietary orange peel extract on physiological, biochemical, and metabolicresponses of Japanese quail reared under low ambient temperature. Turkish Journal of Veterinary and Animal Sciences, 40: 288-297.

[18] Mostafa, F. A., Salem, A. A., Elaby, S. M., Nail, S. N. (2015). Protective Activity of Commercial Citrus Peel Extracts against Paracetamol induced Hepato-nephro Toxicity in Rats. Journal of Chemical, Biological and Physical Sciences, 70-83.

[19] Kusuma, A. S. W. (2015). The Effect of Ethanol Extract of Soursop Leaves (Annona muricata L.) to Decreased Levels of Malondialdehyde . J MAJORITY ,4 (3),14-18.

[20] Maher P, Akaishi T. Abe K. (2006). Flavonoid fisetin promotes erk dependent long term potentiation and enhances memory. PNAS.; 103(44):16568-73

[21] Kurniawati, E., Lestari, E. E. (2016). Uji Efektivitas Daun Belimbing Wuluh (Averrhoa bilimbi L.)Sebagai Pengobatan Diabetes Melitus. Majority, Volume 5 Nomor 2. 